\title{
Situações de uso da linguagem no ensino remoto de língua portuguesa em contexto pandêmico
}

\author{
Situations of language use in remote portuguese language teaching in \\ pandemic context
}

\author{
Situaciones de uso de la lengua en la enseñanza remota de la lengua \\ portuguesa en contexto pandémico
}

\author{
Edmilson Francisco ${ }^{1}$ \\ Ilsa do Carmo Vieira Goulart ${ }^{2}$
}

\begin{abstract}
Resumo: A pandemia mundial da COVID-19 modificou as relações sociais, impondo o distanciamento social e fazendo com que as aulas passassem a acontecer remotamente. Isso levou as instituições educativas a uma busca constante por aprimoramento ou alfabetização digital referente à fluência tecnológica e pedagógica, para conseguirem dar seguimento às rotinas de estudos, de ensino e de aprendizagem. Assim, objetiva-se refletir sobre situações de uso da linguagem no processo de ensino da Língua Portuguesa no contexto pandêmico em escolas públicas por meio de ambientes virtuais, tendo em vista as exigências de novos posicionamentos e estratégias pedagógicas para assegurar o processo de ensino e aprendizagem de forma remota. $\mathrm{O}$ estudo classifica-se como descritivo e explicativo e se ampara nas perspectivas teóricas de estudiosos da linguagem como Bakhtin (2003), Ilari (2001), Fairclough (2006), Freitas (1994; 2010), Isaía (1988), Santos (2015) e Vieira e
\end{abstract}

\footnotetext{
${ }^{1}$ Mestre em Educação pela Universidade Federal de Lavras (UFLA) (2019), Especialista em UEI (Uso Educacional da Internet) pela UNIVERSIDADE FEDERAL DE LAVRAS(2014), Graduado em FILOSOFIA pela UNIVERSIDADE FEDERAL DE SÃO JOÃO DEL REI/MG (2009), Graduado em LETRAS com licenciatura em Português e Inglês pelo CENTRO UNIVERSITARIO DE LAVRAS - UNILAVRAS (2000), Técnico em Processamento de Dados pela Escola da Comunidade Juventino Dias CENEC/LAVRAS/MG)(1995), Professor do Ensino Básico nas disciplinas de Língua Portuguesa e Língua Inglesa na Prefeitura Municipal de Lavras/MG. Áreas e temáticas de interesse: análise do discurso, tecnologias na educação, formação docente, metodologias de ensino de línguas, ensino técnico e profissional. E-mail: ferriceliuei2014@gmail.com ORCID: https://orcid.org/0000-0002-5357-3617

${ }^{2}$ Doutora em Educação pela Faculdade de Educação da Universidade Estadual de Campinas (2013). Mestre em Educação pela Faculdade de Educação da Universidade Estadual de Campinas (2009), na Área: Educação, Conhecimento, Linguagem e Arte. Especialista em Psicopedagogia pela UCB (2005). Graduada em Letras, pela Fundação de Ensino Superior do Vale do Sapucaí (1997). Professora Ajunto A, classe A, do Departamento e Professora Permanente do Programa de Pós-Graduação em Educação da Universidade Federal de Lavras. Tem experiência na área de Educação, com ênfase em Ensino-Aprendizagem, atuando principalmente nos seguintes temas: história da literatura didática brasileira, cultura material escolar, leitura, livro, leitor, alfabetização e práticas de leitura. Coordenadora Adjunta do Programa de Pós-Graduação em Educação da Universidade Federal de Lavras. Coordenadora do Núcleo de Estudos em Linguagens, Leitura e Escrita (NELLE) e do Grupo de Pesquisa Linguagem, Leitura e Cultura Escrita, da Universidade Federal de Lavras. Atuou como Coordenadora do curso de Pedagogia, da Universidade Federal de Lavras (2014-2018). Atuou como coordenadora Adjunta do Programa de Pós-graduação em Educação (2018-2020). Atuou no Conselho Editorial da Revista Devir Educação, da Universidade Federal de Lavras (2016-2019). Membro do Conselho Editorial da Editora UFLA. Membro do Comitê de Ética de Pesquisa com Seres Humanos COEP, da Universidade Federal de Lavras. Membro da Associação de Leitura do Brasil (ALB), desde 2008, da Associação Brasileira de Alfabetização (ABAlf), desde 2014. Membro da Rede de Pesquisadores sobre Leitura Literária, Arte Narrativa e Contação de Histórias. E-mail: ilsa.vieira@uol.com.br ORCID: https://orcid.org/0000-0002-9469-2962
}

Revista Devir Educação, Lavras-MG. Edição Especial, p.450-474, Set./2021. 
Silvestre (2015). Espera-se que este trabalho contribua para uma reflexão acerca do ensino de Língua portuguesa nestes novos tempos, haja vista que, além do conhecimento básico tecnológico, é exigido dos professores e alunos novas competências e habilidades para uso da linguagem para estabelecerem comunicação.

Palavras-chave: Ensino Remoto; Tecnologias digitais; Interação verbal; Língua Portuguesa.

\begin{abstract}
The global pandemic of COVID-19 has changed social relations, imposing social distancing and making classes happen remotely. This led to some crucial questions regarding how, why and what is taught, leading educational institutions to a constant search for improvement or digital literacy related to technological and pedagogical fluency, in order to be able to follow up the routines of studies, teaching and learning. Thus, this article aims to reflect on situations of language use in the process of teaching the Portuguese language in the pandemic context in public schools through virtual environments, in view of the requirements of new positions and pedagogical strategies to ensure the teaching and learning process remotely. The study is classified as descriptive and explanatory and is based on the theoretical perspectives of language scholars such as Bakhtin (2003), Ilari (2001), Fairclough (2006), Freitas (1994; 2010), Isaía (1988), Santos (2015) and Vieira and Silvestre (2015). It is expected that this work will contribute to a reflection on the teaching of Portuguese language in these new times, since, in addition to basic technological knowledge, teachers and students are required new skills and abilities to use language to establish communication.
\end{abstract}

Keywords: Remote Teaching; Digital technologies; Verbal interaction; Portuguese Language.

\title{
Situaciones de uso de la lengua en la enseñanza remota de la lengua portuguesa en contexto pandémico
}

Resumen: La pandemia global de COVID-19 ha cambiado las relaciones sociales, imponiendo el distanciamiento social y haciendo que las clases sucedan de forma remota. Esto llevó a las instituciones educativas a una búsqueda constante de mejora o alfabetización digital relacionada con la fluidez tecnológica y pedagógica, con el fin de poder dar seguimiento a las rutinas de estudios, enseñanza y aprendizaje. Por lo tanto, el objetivo es reflexionar sobre las situaciones de uso de la lengua en el proceso de enseñanza de la lengua portuguesa en el contexto de pandemia en las escuelas públicas a través de entornos virtuales, en vista de los requisitos de los nuevos puestos y estrategias pedagógicas para garantizar el proceso de enseñanza y aprendizaje a distancia. El estudio se clasifica como descriptivo y explicativo y se basa en las perspectivas teóricas de estudiosos del lenguaje como Bakhtin (2003), Ilari (2001), Fairclough (2006), Freitas (1994; 2010), Isaía (1988), Santos (2015) y Vieira y Silvestre (2015). Se espera que este trabajo contribuya a una reflexión sobre la enseñanza de la lengua portuguesa en estos nuevos tiempos, ya que, además de los conocimientos tecnológicos básicos, a los profesores y estudiantes se les requieren nuevas habilidades y destrezas para utilizar el idioma para establecer la comunicación.

Palabras clave: Enseñanza a distancia; Tecnologías digitales; Interacción verbal; Idioma portugués. 


\section{Introdução}

A Organização Mundial de Saúde (OMS), em janeiro de 2020, reconheceu o surto da doença causada pela COVID-19, como uma emergência de saúde pública de importância internacional e, posteriormente, no dia 11 de março de 2020, fora caracterizada como pandemia. O contexto de pandemia mundial modificou as nossas relações sociais, implementando o distanciamento social como medida sanitária de prevenção de contágio.

Em 20 de março, o Senado aprovou o decreto de Estado de Calamidade Pública no Brasil (Decreto legislativo $\mathrm{n}^{\circ}$ 6). Diante disso, as instituições de ensino ficaram impedidas de ministrar aulas presenciais. Contudo, o Ministério de Educação e Cultura (MEC) divulgou a Nota Técnica sobre a Portaria MEC N 544/2020 e o Parecer CNE/CP No 05/2020, que orientaram a reorganização do Calendário Escolar e da possibilidade de cômputo de atividades não presenciais para fins de cumprimento da carga horária mínima anual, em razão da Pandemia da COVID-19, em toda as etapas da educação básica.

Frente a tal situação, o contexto pandêmico exigiu outras formas de pensar as práticas educativas, em que professores e educadores desenvolvessem um processo de ensino e aprendizagem que levasse em consideração as condições sociais, como fator determinante para a elaboração de material didático, de modo a priorizar as reais necessidades de aprendizagem dos alunos, tendo em vista os recursos disponíveis e as condições viáveis da realidade de cada instituição escolar. Com isso, percebemos que um projeto de ensino necessita considerar "a vida que se vive” (MARX; ENGELS, 2006 p. 6), a realidade, os desejos, as emoções, as dificuldades, os sonhos, os desafios dos alunos etc., dado que, se não adequarmos os conteúdos ensinados ao contexto e às necessidades dos estudantes, possivelmente não atingiremos o objetivo pretendido com o processo de ensino $\mathrm{e}$ aprendizagem. Desse modo, este artigo assume como objetivo refletir sobre situações de uso da linguagem no processo de ensino remoto da Língua Portuguesa no contexto pandêmico.

Para isso, apresentamos uma reflexão teórica organizada em seções. Inicialmente trazemos uma perspectiva teórica dos estudiosos da linguagem como processo de interação, com base nos estudos de Bakhtin (2003), Ilari (2001), Fairclough (2006), Freitas (1994; 2010; 2017), Isaía (1988), Santos (2015) e Vieira e Silvestre (2015), incorporando-a à cultura digital. Em seguida nos apoiamos em Bakhtin (2003; 2009), Freitas (2010; 2017) para refletirmos sobre a linguagem como instrumento mediador no processo de ensino e 
aprendizagem, que permite aos professores e alunos interagirem e estabelecerem relações dialógicas nos ambientes virtuais.

Nesse sentido, partimos da premissa de que é, a partir da troca de experiências, do processo de compreensão da fala, do diálogo, do discurso, de intercambiamento de enunciados dos sujeitos envolvidos na comunicação, que supomos dever existir em um ambiente virtual de ensino e aprendizagem que se proponha a ser um recurso tecnológico para fins educacionais.

\section{Da linguagem como interação social à perspectiva do letramento digital}

Trazemos como mote inicial as ideias de Franchi (1992 citado por Ilari, 2001), ao descrever que há uma relação dialética entre linguagem e realidade, dado que "a língua organiza o pensamento, produz ideias e compõe o quadro de referências para o agir do homem no mundo [...] mas o que é fundamentalmente constitutivo é a capacidade que tem de recriar constantemente essa realidade, uma vez que ela é histórica" (FRANCHI, 1992 apud ILARI, 2001, p. 12).

Dessa perspectiva, a linguagem é entendida como trabalho social e histórico que acontece entre sujeitos, para sujeitos e com sujeitos "a historicidade da linguagem, ao mesmo tempo, cria uma nacionalidade cultural e, portanto, móvel, e dá-lhe um dinamismo, que a faz 'aberta aos trabalhos do entendimento' e 'às provocações da imaginação" (grifo do autor).

Desta forma, lançamos um olhar para a questão da utilização da linguagem nas suas instâncias vivas, considerando que o nosso trabalho com a linguagem não pode estar desvinculado do mundo real. A exemplo disso, é perceptível o quanto os aparatos tecnológicos têm revolucionado a comunicação do homem pós-moderno e representado não somente um meio de se comunicar, mas também de se instituir modos de relações e interações sociais, haja vista o que temos vivenciado com o surgimento da pandemia.

Nos últimos anos vimos as relações anteriormente estabelecidas, na maioria das vezes, por meio das redes sociais, internet e/ou ambientes virtuais, tomarem um novo impulso, assim como presenciamos uma revolução na forma como ensinamos e, consequentemente, na maneira como se aprende, mediada por recursos tecnológicos. Destacamos que estas mudanças provocadas pela inserção tecnológica no contexto social e educacional não são iguais às que aconteceram em tempos passados. Ao estudar sobre esta inserção tecnológica, Prensky (2001) descreveu-a, há 20 anos, como uma mudança radical, singular, ou seja, sem volta, em que os alunos contemporâneos não pensariam e processariam as informações como 
os das gerações passadas. Acerca disso, advogamos que os professores não podem ignorar tais mudanças e suas implicações para o processo educativo. Fardo (2013) afirma que os métodos tradicionais de ensino praticados pela maioria das escolas brasileiras já não são mais capazes de atender as demandas dos alunos que incorporam cada vez mais as características da cultura digital.

Os alunos de hoje não são os mesmos para os quais o nosso sistema educacional foi criado. Os alunos de hoje não mudaram apenas em termos de avanço em relação aos do passado, nem simplesmente mudaram suas gírias, roupas, enfeites corporais, ou estilos, como aconteceu entre as gerações anteriores. Aconteceu uma grande descontinuidade. Alguém pode até chamá-la de apenas uma "singularidade" - um evento no qual as coisas são tão mudadas que não há volta (PRENSKY, 2001, p. 1).

Verificamos ainda que não ocorreram apenas modificações comportamentais nos alunos, mas também na forma como estes alunos se comunicam. No entanto, no que tange ao uso da linguagem no ambiente escolar, nota-se que de forma lenta e restrita a poucas instituições escolares, o processo de comunicação sofreu alterações, interferindo na maneira como a linguagem é utilizada, organizada e no modo como nós, professores, falamos e nos comunicamos com nossos alunos, uma vez que parte dessa comunicação passou a ser feita por meio de ambientes virtuais. Ou seja, algumas instituições escolares, mesmo antes da pandemia, inseriram nas ações administrativas uma forma de interação com a comunidade por meio do correio eletrônico, de páginas em redes sociais ou criação de blogs ou sites com divulgação de ações da instituição, ou, ainda, com a criação de blogs por professores como forma de socialização de atividades, como destaca a pesquisa de Francisco (2019). Contudo, muitas escolas só se atentaram para a urgência e necessidade do uso das tecnologias digitais nas salas de aula com a pandemia, passando a considerar como importante o desenvolvimento das aulas nos ambientes virtuais. Frente a essa redefinição da expressão da linguagem mediada pelos recursos digitais, em que as relações interpessoais alteraram-se, segundo Fairclough (2006), ocorrem "recontextualizações da linguagem", ligadas de modo intrínseco a aspectos como: discurso e linguagem; poder; relações sociais; práticas sociais; instituições e rituais; crenças; valores e desejos (VIEIRA; SILVESTRE, 2015, p. 30).

As "recontextualizações da linguagem" citadas por Fairclough (2006) e as teorias desenvolvidas por Bakhtin (2009) se coadunam ao trazerem uma concepção de linguagem fundamentada em uma perspectiva sociocultural, apontando-a não como um sistema formal 
de normas, mas na sua eventicidade, nos enunciados criados e que sempre geram uma resposta, uma tomada de "posição axiológica" (FREITAS, 2010, p. 14).

Para Bakhtin (2003), a linguagem é formada por enunciados, compreendidos para a unidade da língua que se constitui de pleno sentido, porque dirige-se a alguém e provoca neste outro uma resposta, por isso

[...] a enunciação é o produto da interação de dois indivíduos socialmente organizados e, mesmo que não haja um interlocutor real, este pode ser substituído pelo representante médio do grupo social ao qual pertence o locutor. A palavra dirige-se a um interlocutor: ela é função da pessoa desse interlocutor: variará se se tratar de uma pessoa do mesmo grupo social ou não, se esta for inferior ou superior na hierarquia social, se estiver ligada ao locutor por laços sociais mais ou menos estreitos (pai, mãe, marido, etc.) Não pode haver interlocutor abstrato; não teríamos linguagem comum com tal interlocutor, nem no sentido próprio nem no figurado" (grifo do autor).

Conforme Bakhtin (2003), são os participantes da fala, juntamente com uma situação social bem precisa ou instituída, que determinam o estilo e a forma da enunciação. Embora a situação social, em contexto de pandemia causada pela COVID-19, ser indefinida e instável, estabelece-se aos participantes da fala (BAKHTIN, 2003) uma situação distinta, em que professores e alunos precisam assumir outra forma de comunicação para estabelecer uma condição de ensino e aprendizagem em meio ao distanciamento social.

Neste contexto pandêmico, fez-se necessário pensar em um trabalho pedagógico com a linguagem concebido, fundamentado ou determinado por uma perspectiva social, como dito por Fairclough (2006) e Bakhtin (2003), considerando, no ensino da língua portuguesa, a eventicidade da língua (gem), ou seja, promover um ensino da língua materna em que o uso da língua e linguagem estejam vinculados aos contextos e situações sociais dos quais os alunos fazem parte e da situação social vivida. Somado a isso, a que se pensar que o diálogo a ser estabelecido entre professores e alunos, dentro das salas de aula virtuais, necessita acontecer de uma maneira diferente da que ocorre presencialmente, pois nesse modo, mesmo que os sujeitos ocupem lugares diferentes na hierarquia social, a comunicação acontece baseada nos recursos que um e outro dispõem no momento da interlocução. Ou seja, mesmo que a bagagem linguística de cada um seja diferente, tanto professor quanto alunos re(organizam) os enunciados criados para que estes gerem respostas e haja entendimento. Já o uso da língua(gem) em ambientes digitais toma uma nova forma, pois a interação verbal que se pretende estabelecer é mediada por dispositivos digitais que exigem dos sujeitos um 
conhecimento básico destes recursos tecnológicos, o que se denomina de letramento digital (RIBEIRO; COSCARELLI, 2014).

Conforme descrevem Ribeiro e Coscarelli (2014, p.181), o letramento digital pode ser definido como "as práticas sociais de leitura e produção de textos em ambientes digitais", o que compreende os usos que fazemos socialmente de textos em ambientes digitais, propiciados pelo computador ou por dispositivos móveis, tais como celulares e tablets, em plataformas como e-mails, redes sociais na web, entre outras possibilidades.

A definição proposta por Ribeiro e Coscarelli (2014) nos leva a refletir sobre a necessidade do uso dos aparatos digitais nas aulas de língua portuguesa para que os alunos experienciem praticar leitura nos ambientes digitais, dado que muitos destes alunos já fazem uso destes recursos, "navegam" na internet, se deparam com diversos gêneros textuais, mas ainda não possuem habilidades e competências para lidar com estes textos como fonte de informação e aprendizado. Neste sentido, Xavier (2005, p. 1) alega que:

O crescente aumento na utilização das novas ferramentas tecnológicas (computador, Internet, cartão magnético, caixa eletrônico etc.) na vida social tem exigido dos cidadãos a aprendizagem de comportamentos e raciocínios específicos. Por essa razão, alguns estudiosos começam a falar no surgimento de um novo tipo, paradigma ou modalidade de letramento, que têm chamado de letramento digital. Esse novo letramento, segundo eles, considera a necessidade de os indivíduos dominarem um conjunto de informações e habilidades mentais que devem ser trabalhadas com urgência pelas instituições de ensino, a fim de capacitar o mais rápido possível os alunos a viverem como verdadeiros cidadãos neste novo milênio cada vez mais cercado por máquinas eletrônicas e digitais.

O referido autor aponta a urgência de as instituições escolares desenvolverem um processo de ensino e aprendizagem que possibilite aos alunos dominarem um conjunto de informações e habilidades mentais que os capacite a viverem como cidadãos neste milênio, não sendo excluídos dos avanços tecnológicos ocorridos. E o surgimento da pandemia trouxe à tona essa urgência, fazendo com que as Secretarias de Educação e as escolas desenvolvessem planos e projetos educacionais para que o processo de ensino tivesse continuidade.

Nessa direção, atendendo às novas exigências que o contexto pandêmico tem imposto, para desenvolverem a sua prática pedagógica, os docentes passaram a executar tarefas complexas referentes à operação dos dispositivos móveis e dos computadores, apropriando-se dos recursos fornecidos por estas tecnologias. O ligar e desligar o computador, o uso do mouse, do teclado, da barra de rolagem, o acessar links e a criação de formulários de respostas 
on-line são alguns exemplos de tarefas que nós, professores, passamos a utilizar frequentemente em nossa prática cotidiana de ensino.

Ribeiro (2016, p. 21) cita que “o letramento digital parte desse pluralismo". A autora afirma que, além destas tarefas já realizadas pelos professores no modo presencial, passaram a realizar curadoria, selecionando informações relevantes e confiáveis na web, navegando em sites de pesquisa e definindo a linguagem mais apropriada a ser utilizada on-line. E isto, segundo a autora, "são exemplos de competências que ultrapassam o conhecimento da técnica”. (RIBEIRO, 2016, p. 21).

Somado a isso, o ambiente virtual tem requerido dos professores de língua materna a realização de "práticas de leitura e escrita diferentes das formas tradicionais de letramento e alfabetização", assim como mudanças na forma como se lida com a leitura, com a escrita e com a linguagem verbal e não verbal, dado que o suporte sobre o qual estão os textos digitais é a tela, também digital.

$\mathrm{O}$ contexto pandêmico trouxe a necessidade de se inserir no processo de ensino e aprendizagem, como meios para se realizarem as aulas, os aparatos tecnológicos e as tecnologias digitais. Mesmo aquelas escolas consideradas "desconectadas" precisaram reestruturar o seu plano de ensino para conseguirem atender ao que o contexto pandêmico exige. Nesse processo de reestruturação, as instituições escolares e a comunidade escolar perceberam o quanto é necessário aprender a operar os dispositivos digitais, assim como buscar formação quanto ao uso das tecnologias e dos aparatos digitais para conseguirem levar à frente o plano educacional. Aqui não consideramos apenas a formação técnica, mas também a mudança de comportamentos e atitudes perante a esse contexto, que também tem "exigido" dos professores outras posturas quanto ao seu papel de mediador de aprendizagem. Como parte do ensino passou a ser realizado on-line, em ambientes virtuais, o processo de comunicação e interação entre alunos e professores mudou. No entanto, muitos de nós, professores, não nos sentíamos preparados para fazer uso de tais interfaces nem sala de aula física quanto mais na on-line. Assim, percebemos que, para darmos seguimento ao processo de ensino, precisávamos aprender a operar os recursos digitais e a conhecer as tecnologias, mesmo que de forma básica, para podermos nos comunicar com nossos alunos e instrui-los. Percebemos ainda que, se tais mudanças e buscas não fossem consideradas, possivelmente encontraríamos dificuldades em nossa prática pedagógica. 
Desse modo, o letramento digital tornou-se uma grande estratégia para o enfrentamento de problemas relacionados ao uso das tecnologias e dos recursos tecnológicos e para a superação das dificuldades surgidas com o distanciamento social, no que tange à comunicação entre professores e alunos, uma vez que, se o professor não estiver "seguro" acerca da operação dos recursos digitais ou não estiver "preparado" para solucionar os possíveis problemas que vierem a surgir durante as aulas on-line, possivelmente o objetivo traçado para a aula não será alcançado. Da mesma forma, se os alunos não tiverem um nível básico de letramento digital para operar os dispositivos digitais, ativando os recursos para que possam aprender por meio deles, possivelmente terão dificuldade em apreender o conteúdo ora passado pelo professor. Diante disso, o processo de interação verbal a ser estabelecido entre o professor e os alunos estará comprometido, dado que ambos são parceiros da enunciação, visto que a "[...] enunciação é o produto da interação de dois indivíduos socialmente organizados [...]" (BAKHTIN, 2003, p. 114). Com base nesta perspectiva de linguagem, Freitas (1994, p. 138) descreve que:

Foi a partir de uma concepção dialógica da linguagem que Bakhtin afirmou sua verdadeira substância, constituída pelo fenômeno social da interação verbal. Ignorar a natureza social e dialógica do enunciado seria apagar a profunda ligação existente entre a linguagem e a vida. Os enunciados não existem isolados: cada enunciado pressupõe seus antecedentes e outros que o sucederão; um enunciado é apenas um elo de uma cadeia, só podendo ser compreendido no interior desta cadeia.

Na visão de Bakhtin (2003), observando a organização da linguagem no que se refere ao tema enunciado (texto) e aos sujeitos da enunciação, estes se constituem como elementos decisivos na dinâmica do envolvimento e da vontade enunciativa, ou seja, o querer-dizer do falante ou locutor é que determinam a escolha do gênero e a realização concreta do enunciado:

A vontade enunciativa do falante se realiza antes de tudo na escolha de um gênero do discurso. Essa escolha é determinada pela especificidade de um dado campo da comunicação discursiva, por considerações semânticoobjetais (temáticas), pela situação concreta da comunicação discursiva, pela composição pessoal dos seus participantes etc. (BAKHTIN, 2003, p. 282, ênfase texto original).

Ao escolhermos um gênero discursivo para produzir um determinado enunciado, entendemos que este fará diferença na forma como nos dirigimos aos interlocutores, pois a enunciação se define pelas possibilidades deixadas pela esfera/campo de comunicação em que se dá (ROJO; BARBOSA, 2015). De acordo com Rojo e Barbosa (2015, p. 77), com base na 
perspectiva enunciativa discursiva de Bakhtin, os "gêneros discursivos são as formas de dizer mais ou menos estáveis na sociedade". Assim, neste contexto pandêmico, em que as aulas acontecem de forma remota por meio de ambientes virtuais, que os sujeitos do discurso (professores e alunos) se debruçam sobre o que aponta Bakhtin (2003) no que se refere às escolhas do gênero do discurso. O momento tem exigido que nós, professores de língua portuguesa, levemos em consideração as temáticas a serem abordadas em nossa prática pedagógica, assim como também na situação concreta e real da qual os nossos alunos fazem parte e considerar, ainda, quem são estes alunos. Do contrário, estaremos ignorando a natureza social e dialógica do enunciado e apagando a profunda ligação existente entre a linguagem e a vida.

Segundo Bakhtin (2003), na relação a ser construída entre os sujeitos (emissor e receptor), no contexto social, distinguem-se "dois pólos limites" (Bakhtin, 2003, p. 117) e, tanto um lado quanto o outro tem suas elaborações ideológicas e tomadas de consciência próprias. Isso quer dizer que, quando o emissor, em razão de sua atividade mental, provoca uma reação no receptor por meio de uma informação e, o receptor, consequentemente, responde à elaboração feita pelo emissor. O receptor toma consciência do que foi elaborado pelo emissor e estrutura uma resposta por meio de uma elaboração ideológica própria, a partir de suas experiências e concepções socialmente construídas.

Para explicar sobre a existência de dois polos entre os sujeitos (emissor e receptor) que intentam construir uma relação, Bakhtin se utiliza da metáfora da fome para explicar que a maneira como cada indivíduo enxerga, reage e pensa sobre a fome, depende do contexto e do grupo do qual este sujeito faz parte. Para Bakhtin (2003), "a situação social determina que modelo, que metáfora, que forma de enunciação servirá para exprimir a fome a partir das direções inflexivas da experiência" (BAKHTIN, 2003, p. 119). O autor elucida que a fome, como um "outro sujeito", provoca reações diferentes em sujeitos pertencentes a grupos e contextos sociais diferentes, por isso:

[...] a atividade mental desse indivíduo isolado, sem classe, terá uma coloração específica e tenderá para formas ideológicas determinadas, cuja gama pode ser bastante extensa: a resignação, a vergonha, o sentimento de dependência e muitas outras tonalidades tingirão a sua atividade mental. (BAKHTIN, 2003, p. 118).

Ao usar esta metáfora, Bakhtin (2003) explica que, dependendo do grupo social e do contexto do qual fazemos parte, nele enunciando e expressando, as reações, as respostas às elaborações e às enunciações feitas "pelos outros", pertencentes ao nosso grupo ou não, serão 
diferentes, dado que cada grupo e contexto social possuem elaborações ideologicamente diferentes. Da mesma forma, a resposta do receptor poderá causar no emissor uma mudança de postura ou refazimento de sua enunciação, sob a condição de, caso não a refaça, não ser compreendido, incorrendo em uma "construção reta, criada sem considerar os dados concretos da expressão social" (BAKHTIN, 2003, p. 120). Para o autor, o discurso, a enunciação e as expressões só são reais quando entram em contato com o contexto social real e participantes reais nos quais efetivam sua objetivação. Desse modo, as categorias bakhtinianas do contexto de produção podem ser resumidas como: (1) parceiros da interação (locutor e destinatário), (2) objetivos da interação, querer-dizer do locutor, (3) a esfera onde ocorrerá a interação, que delimita o contexto da situação, com suas marcas ideológicas, sociais e culturais, (4) tema e (5) o gênero escolhido (e suas formas realizáveis).

Neste sentido, advogamos que a prática pedagógica do professor de português no período pandêmico pode ter como base estes subsídios teóricos, em que a linguagem verbal e multimodal necessita se basear no contexto real, de modo que os professores, ao construir enunciados, direcionem a prática, a temática e o gênero a ser ensinado para o "local" onde os alunos vivem, têm suas experiências, onde aprendem socialmente e culturalmente.

\subsection{Interações recíprocas via linguagem no contexto de aulas on-line}

Segundo Freitas (2020, p. 27), a linguagem é de suma importância, visto que passa a ser um "[...] instrumento mediador que permite aos professores e alunos entrelaçarem-se no processo de produção do conhecimento como elementos constitutivos do ensino e da aprendizagem".

Por ser a linguagem dialógica, por provocar no outro uma ação responsiva, para Freitas (2020, p. 22), a “[...] prática pedagógica supõe essas relações interpessoais nas quais ocorrem interações recíprocas via linguagem de um sujeito ativo com outros sujeitos ativos". Os dizeres de Freitas (2020) nos admoesta a pensarmos no ensino da língua portuguesa como algo dinâmico e que envolve dois sujeitos ativos: de um lado o professor como mediador do ensino e do outro lado o aluno, que não é um sujeito passivo, que apenas recebe as instruções do professor, mas alguém que, à medida que se apropria dos conceitos, os reelabora, buscando novas formas de pensar e conceber o mundo, construindo seu conhecimento. Mas, para que isso aconteça com o aluno, o papel do professor como intermediário se torna preponderante, pois nessa dinâmica, a linguagem se torna um veículo em que os dois sujeitos (alunos e 
professores) estabelecem trocas; ora o professor enuncia e o aluno responde, ora o aluno enuncia e o professor responde). Dessa forma, a aprendizagem vai se concretizando por meio da linguagem.

Como descreve Isaía (1988, p. 21-34), a linguagem é:

[...] veículo responsável, não só pela apropriação dos conhecimentos já produzidos e pela geração de novos, como também pelo repasse dos mesmos. Saliento ainda que, além de veicular conhecimento, a linguagem incorpora em si as transformações cognitivas relativas à apropriação deste ao longo da história humana, determinando assim alterações nas funções psicológicas superiores de todos àqueles (no caso, professores e alunos) que a utilizam, buscando novas formas de pensar e conceber o mundo, bem como de operar sobre ele [...] Nesse processo cognitivo-educativo, $[\ldots]$ cabe aos professores serem intermediadores entre os conhecimentos, procedimentos e valores, gerados pela cultura humana ao longo de sua história, e, a diligência dos alunos em adquiri-los, repensá-los e transformálos.

Comprende-se que a linguagem, além de veicular conhecimento, propicia aos sujeitos a possibilidade de se transformam em seres culturais humanos, encontrando sua verdadeira localização social e histórica.

Acerca da linguagem, Isaía (1988) argumenta que ela torna efetivo o conhecimento transmitido e que as transformações intelectuais ocorridas na história humana são também absorvidas por ela. Isaía (1988) declara que a linguagem possui uma tripla função: veicular conhecimento, fazer com que o conhecimento seja absorvido e, uma vez absorvido, causar modificações no intelecto e na mente dos sujeitos. Desse modo, se é nossa incumbência, como professores, orientar e direcionar os alunos no processo de apropriação e obtenção de conhecimentos, é imprescindível que coloquemos à disposição desses alunos, instrumentos que os possibilitem se apropriar das novidades trazidas pelos aparatos culturais e tecnológicos e das transformações cognitivas relativas às essas apropriações e, consequentemente, desenvolverem-se.

Os dispositivos digitais poderão colaborar para o desenvolvimento intelectual dos alunos se, por meio destas ferramentas, forem estabelecidas trocas entre sujeitos envolvidos no jogo da comunicação linguística - trocas de enunciados e estabelecimento de relações dialógicas. No que tange às trocas de enunciados, o produto destas trocas, "o resultado da interação de dois indivíduos socialmente organizados" (BAKHTIN, 2003, p. 114), ou seja, a enunciação, é determinado pelo grupo social ao qual pertence os locutores (emissor e receptor/professor e aluno) e pelo contexto/situação social onde o diálogo ocorre. Bakhtin 
(2003, p. 114, grifo do autor) nos diz que "Qualquer que seja o aspecto da expressãoenunciação considerado, ele será determinado pelas condições reais da enunciação em questão, isto é, antes de tudo pela situação social mais imediata".

É a situação social mais imediata que determina a enunciação. Desse modo, a maneira como os professores enunciam, para quem enunciam e porque enunciam, é determinada pelo contexto/situação social e em condições reais para que essa enunciação não se configure em uma "enunciação monológica".

Bakhtin (2003) afirma que a "enunciação monológica se apresenta como um ato puramente individual, de seus desejos, suas intenções, seus impulsos criadores, seus gestos, etc." (BAKHTIN, 2003, p. 113), mas que não "se configura como expressão, pois tendo se formado e determinado de alguma maneira no psiquismo do indivíduo", não "exterioriza-se objetivamente para outrem com a ajuda de algum código de signos exteriores". O autor explica que, "atividades mentais isoladas, ou mesmo sequências inteiras podem tender para o pólo do $e u$, prejudicando assim sua clareza e sua modelagem ideológica, e dando provas de que a consciência foi incapaz de enraizar-se socialmente" (BAKHTIN, 2003, p. 117). Compreendemos assim, que para que haja enunciação é necessária a existência de dois interlocutores, socialmente organizados, para que as trocas de enunciados e relações dialógicas aconteçam. Nos dizeres de Bakhtin, “[...] a situação e os participantes mais imediatos determinam a forma e o estilo ocasionais da enunciação. Os estratos mais profundos da sua estrutura são determinados pelas pressões sociais mais substanciais e duráveis a que está submetido o locutor" (BAKHTIN, 2003, p. 116).

Como já dito, a enunciação é determinada pelos participantes no ato da fala e pela situação que dá forma a esta enunciação. O autor mencionado afirma que é o contexto social que determina quais serão os ouvintes possíveis, amigos ou inimigos, e para quais a consciência será orientada. O conhecimento do contexto social e do grupo participante são determinantes para a forma como nos dirigimos para outros sujeitos. $\mathrm{O}$ autor defende, ainda, que a situação social determina certo modelo de expressão, de metáfora, ou forma de enunciação, tipos de trocas e de relações dialógicas que serão utilizadas e estabelecidas entre os sujeitos envolvidos no diálogo ou no processo de comunicação.

Nas trocas e relações dialógicas, é necessário que um processo de compreensão responsiva seja organizado. Bakhtin (2003, p. 271) alega que "Toda compreensão da fala viva, do enunciado vivo é de natureza ativamente responsiva [...] toda compreensão é prenhe 
de resposta, e nessa ou naquela forma a gera obrigatoriamente: o ouvinte se torna falante", e continua:

"compreender é opor à palavra do outro uma contrapalavra", haja vista que, ao "Compreender a enunciação de outrem significa orientar-se em relação a ela, encontrar seu lugar adequado no contexto correspondente. A cada palavra da enunciação que estamos em processo de compreender, fazemos corresponder uma série de palavras nossas, formando uma réplica (BAKHTIN, 2009, p. 137, grifo do original).

Segundo Freitas (2010, p. 5), “esse processo compreensivo bakhtiniano supõe duas consciências, dois sujeitos que se interpenetram, intercambiam enunciados, buscam respostas, resistem, argumentam e se alteram mutuamente". Vale dizer que o discurso proferido pelos sujeitos envolvidos no processo de comunicação é dotado de reversibilidade, ou seja, uma vez materializado (expresso), exercerá um efeito na mente do receptor. O receptor da mensagem reagirá e, consequentemente, responderá ao emissor a partir de seu estado de consciência, de suas experiências vivenciadas no contex to e grupo social dos quais participa.

Diante do exposto, concordamos com Lopes, Vieira e Gabriel (2020, p. 6) ao falarem da

[...] importância de utilizar uma linguagem contextualizada como forma de aumentar as possibilidades de comunicação em situações reais; a linguagem compreendida como um instrumento facilitador no processo da comunicação interativa; o impedimento de engessar a linguagem, pois a tecnologia é movimento, ou seja, está em constante renovação; a clareza de que as formas tradicionais de escolarização já não são mais suficientemente adequadas para atender a diversidade de alunos em instituições de ensino, requerendo um ajuste do sistema educativo como a inserção de TIC's [...].

Dado que as tecnologias digitais e os ambientes virtuais se renovam constantemente, há que pensarmos que a linguagem não é engessada, estática. Desse modo, como defendido por Faircloug (2006), nós, professores de língua portuguesa, necessitamos "recontextualizar a linguagem", adequando-a ao ambiente virtual de ensino, pois, do contrário, não alcançaremos o nosso objetivo, transpondo para o ambiente virtual o que é próprio do presencial.

\subsection{Situações de ensino e aprendizagem da língua portuguesa em contexto de pandemia}

Com o distanciamento social e com a necessidade de utilizarmos os recursos tecnológicos, tivemos que reconfigurar a nossa prática pedagógica, inserindo nela tais aparatos. Para conseguirmos dar continuidade ao processo de ensino de língua portuguesa neste período de pandemia, nos valemos de algumas estratégias. Como muitos professores 
não se utilizavam destes recursos em sala de aula, a Secretaria Municipal de Educação do município desenvolveu, no período de 16 a 27 de julho de 2020, uma formação com o intuito de preparar os docentes para enfrentar a nova realidade que se apresentava.

Após um planejamento cuidadoso da Secretaria de Educação, inicialmente, nós, professores, passamos pelo período de treinamento que abordou temas didático-pedagógicos (Ensino Remoto Emergencial: possibilidades e desafios, Planejar: significado, pertinência e relevância em tempos de Ensino Remoto para podermos levar adiante o processo de ensino e aprendizagem, Estilos de Aprendizagem: Inteligências múltiplas, Saúde do professor e cuidados com a Pandemia, Elaboração de material didático), como também sobre usos das tecnologias digitais, aparatos tecnológicos, ferramentas e plataformas digitais (Google Meet, Google Classroom, GSuíte for Education, Google Hangout, Google formulários etc).

O treinamento proposto nos levou a refletir sobre as possibilidades de uso das tecnologias digitais em sala de aula, considerando as condições de acesso, fluência tecnológica e conhecimento dos alunos e dos professores acerca de tais tecnologias para aprendizagem. Terminado o treinamento, passamos a elaborar o material didático, chamado de REO (Roteiro de Estudos Orientados), um documento orientador aos estudantes em seu processo de aprendizagem. Tal documento trazia algumas perguntas ( $\mathrm{O}$ que? (do que se tratava); Por que? (a razão do assunto do material didático); Para que? (o objetivo daquele conteúdo); O que já sabemos (retomada sobre conteúdos já aprendidos); O que vamos aprender? (apresentação e explicação do conteúdo a ser aprendido); O que preciso fazer para aprender? (orientações sobre estratégias de aprendizagem)), que tinham como objetivo desencadear ações de aprendizagem, possibilitando ao aluno compreender o porquê de determinados conteúdos e atividades estarem sendo abordados naquele material.

Em seguida, os professores de cada instituição escolar criaram grupos de cada turma no Whatsapp para estabelecerem contato e se reaproximarem dos alunos. Os grupos criados foram utilizados para os professores orientarem os alunos sobre como as aulas seriam realizadas, sobre como e quais ambientes virtuais seriam utilizados, frequência das aulas, disponibilização de material didático, devolutiva das atividades etc. Quanto ao como e quais dispositivos ou plataformas digitais utilizaríamos, fizemos, antes de começarem as aulas online, alguns workshops com os alunos e seus responsáveis, ensinando-os a acessarem e realizarem atividades nestes dispositivos (Figura 1). Estes workshops foram gravados e disponibilizados para os alunos em nosso canal no Youtube. 


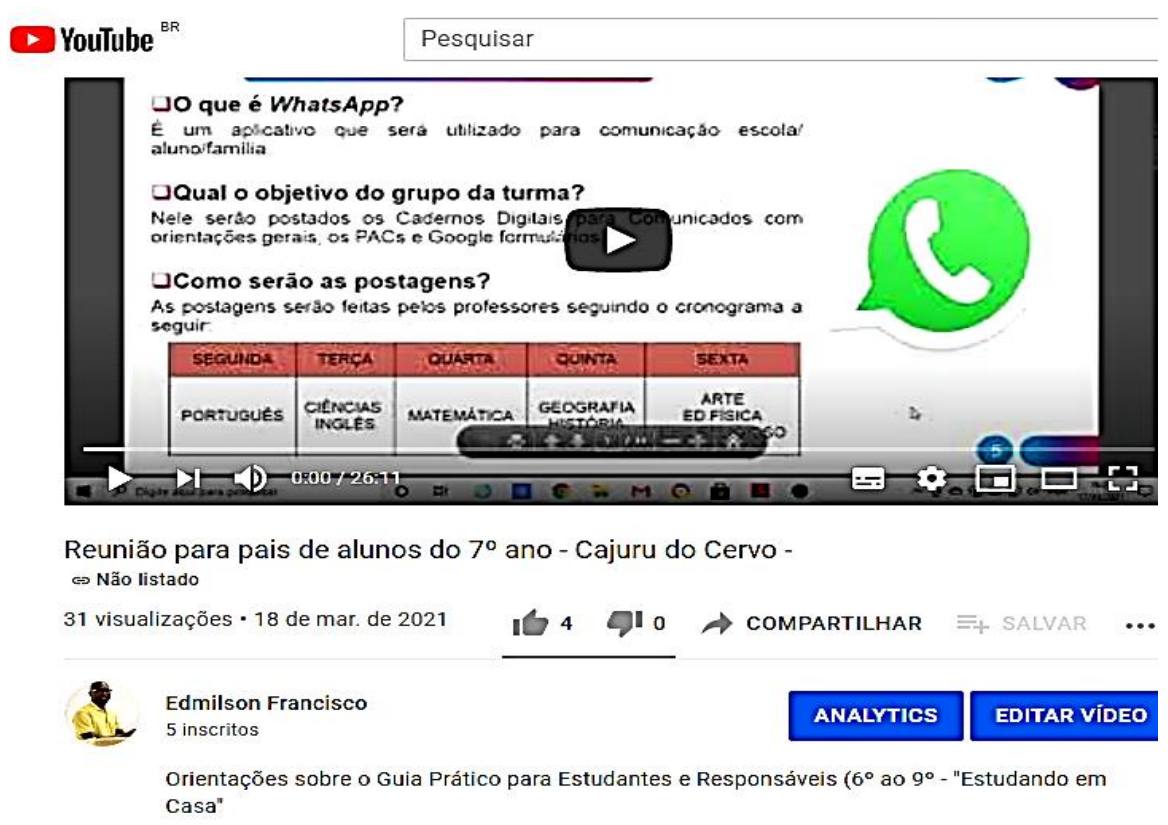

Figura 1: $1^{\circ}$ Workshop com pais e alunos sobre uso de aplicativos e dispositivos digitais nas aulas on-line de língua portuguesa. (https://youtu.be/H6u8wcYwV_o) Fonte: Dos autores (2021)

No $2^{\circ}$ semestre de 2020, utilizamos os REOS (Roteiros de Estudos Orientados), disponibilizando-os no formato pdf no Google Classroom e, ao mesmo tempo, este mesmo material era impresso pela Secretaria de Educação e enviado para as escolas para os alunos. Os alunos retiravam o material na escola e, depois, devolviam com as respostas.

No início de 2021, devido ao agravamento da pandemia, a Secretaria de Educação do município redefiniu os modos como as aulas seriam desenvolvidas e como o material seria disponibilizado para os alunos. Então, passamos a utilizar com mais frequência os grupos das turmas no Whatsapp e a plataforma digital Google Meet. Por meio dos grupos no Whatsapp damos avisos e enviamos o material didático para os alunos no formato pdf (que passou a ser chamado de PAC - Plano de Atividades em Casa) etc., como pode ser visto nas Figura 2, 3 e 4, abaixo. 


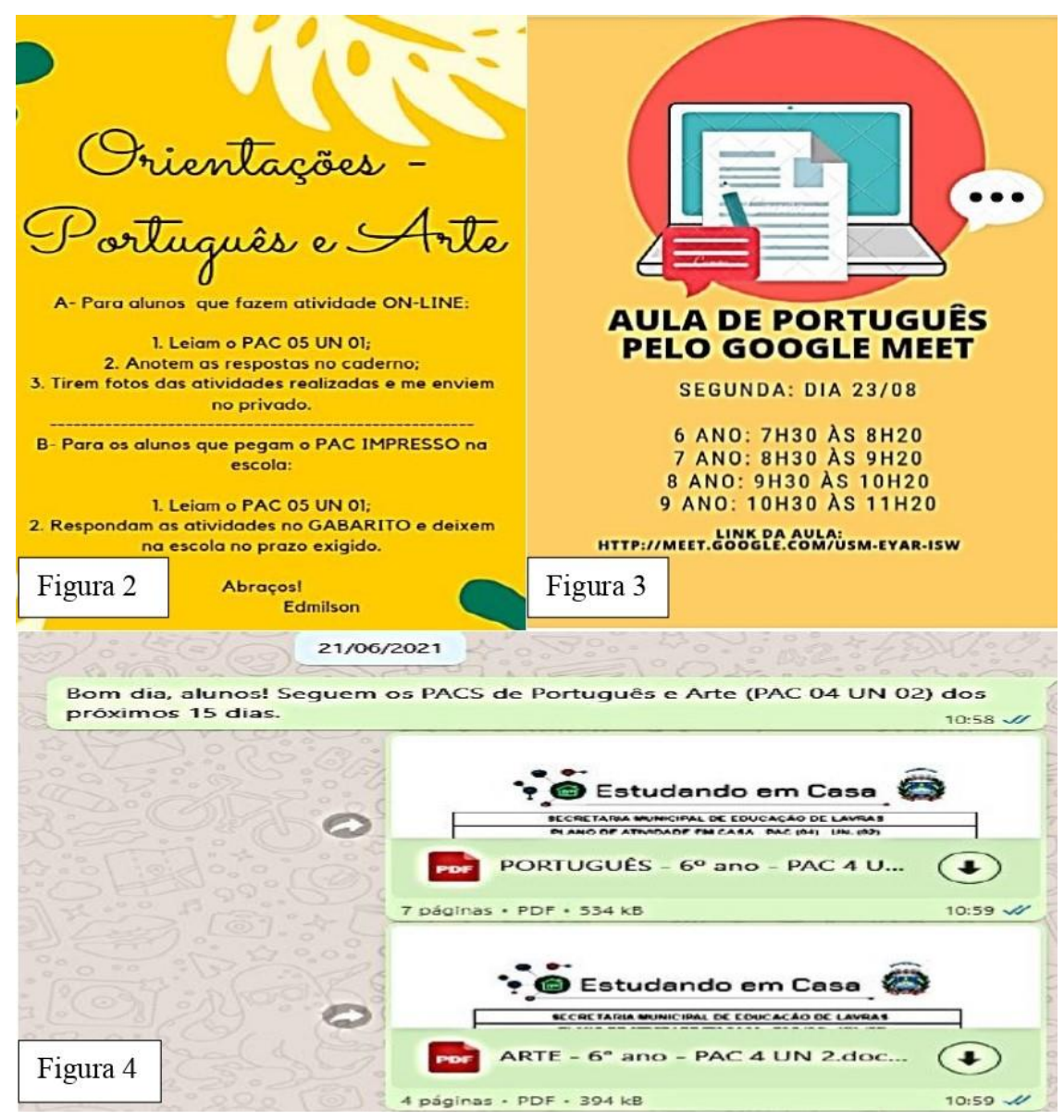

Figura 2, 3 e 4: Avisos, informações sobre o horário e link para acesso às aulas e material didático (PAC) em formato pdf enviados para os alunos

Fonte: Dos autores (2021)

O PAC traz a mesma estrutura do REO, apenas com algumas poucas modificações.

Ele é enviado para os alunos quinzenalmente e, no final destes 15 dias, as respostas são enviadas para os professores. Inicialmente, os alunos tiravam fotos das respostas e enviavam para o professor da disciplina, no privado. Posteriormente, passamos também a utilizar o Google Formulários (Figura 5), um serviço gratuito para criar formulários online, em que o usuário pode produzir pesquisas de múltipla escolha, fazer questões discursivas, solicitar avaliações em escala numérica, entre outras opções, como mais uma opção de uso das tecnologias digitais em sala de aula. 


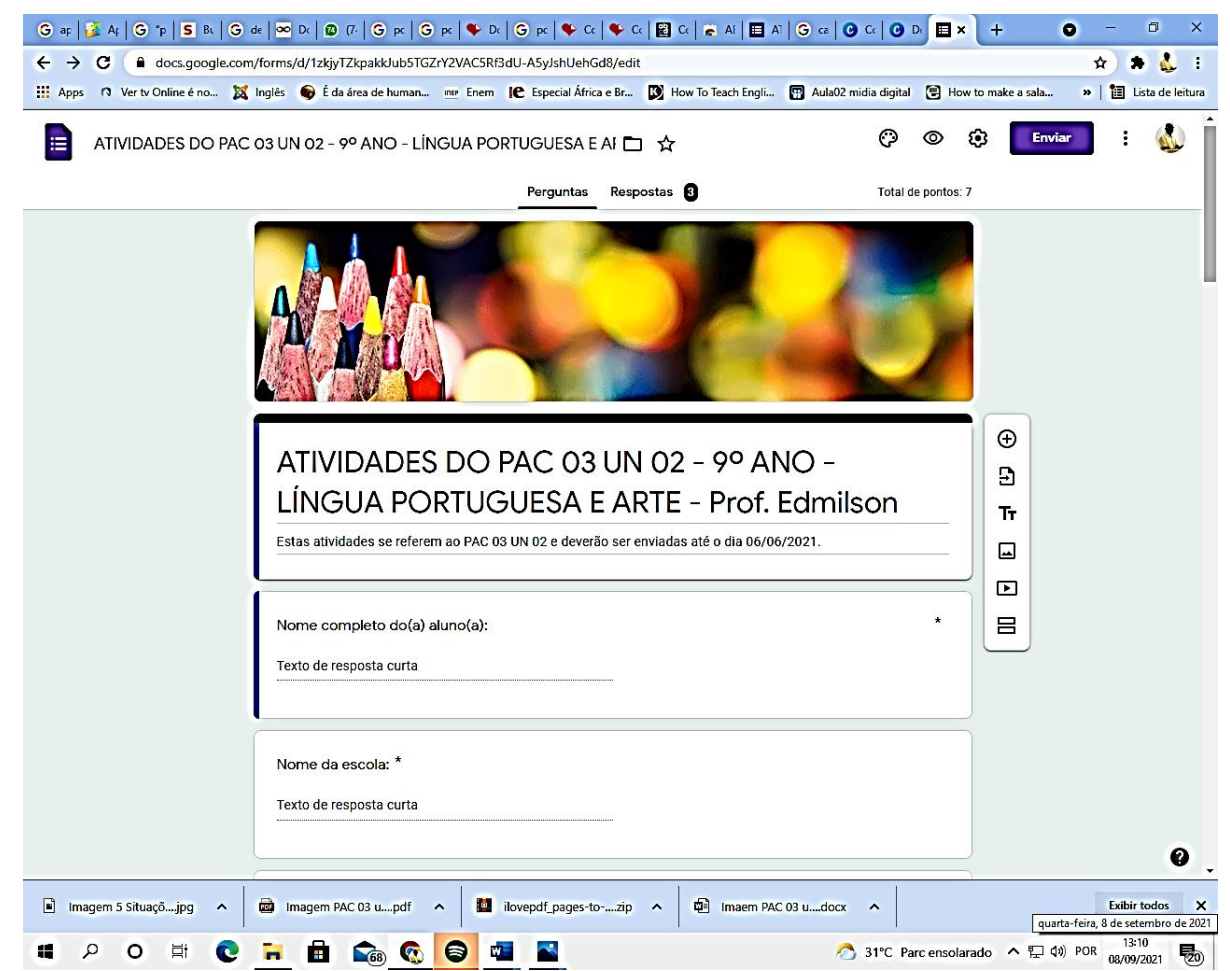

Figura 5: Formulário disponibilizado no Google Formulários para respostas on-line Fonte: Dos autores (2021)

Neste novo processo de ensinar e aprender, fomos, o tempo todo, orientados pela Secretaria de Educação, que nos deu todo aporte necessário. No entanto, a prática pedagógica, o como ensinar, as metodologias e as estratégias a serem utilizadas no desenvolvimento das aulas on-line constituíram-se como responsabilidade do professor. Diante disso, cada professor necessitaria buscar o seu caminho, a sua forma de dar aula neste novo formato, ou seja, on-line.

Posto isto, para as aulas de língua portuguesa on-line nos apoiamos nos dizeres de Bakhtin (2003), no que tange ao uso da linguagem, levando-se em consideração os elementos (sujeitos) participantes do jogo linguístico para escolhermos os gêneros a serem trabalhados e a realização concreta do enunciado. Nos pautamos em planejar e organizar as aulas, que passaram a ser realizadas on-line e remotamente, considerando a "situação concreta da comunicação discursiva, pela composição pessoal dos seus participantes etc". (BAKHTIN, 2003, p. 282).

A situação concreta de comunicação foi determinada pelo distanciamento social imposto pela pandemia, assim como pelo contexto social dos alunos. Em nosso caso, os alunos vivem na zona rural e, grande parte deles, não tem acesso à internet e não possuem recursos tecnológicos (computadores, celulares, tablets ou qualquer dispositivo digital) para 
acompanhar as aulas. Optamos, então, por oferecer aos alunos o material didático on-line (via Whatsapp) e também impresso. Para os alunos com acesso à internet, as atividades estariam disponibilizadas pelo Whatsapp, enviariam as respostas por meio de fotos e diretamente no Google Formulários e, para aqueles que sem acesso à internet, pegariam as atividades na escola, devolvendo, após 15 dias, apenas o gabarito respondido, contido no PAC.

Na Figura 6, vemos um exemplo de como desenvolvemos uma de nossas aulas online. Nas aulas on-line pelo Google Meet, escolhemos estruturá-las da seguinte forma: Boasvindas, Leitura deleite, Estudo do vocabulário e Correção das atividades do Plano de Atividades em Casa (PAC).

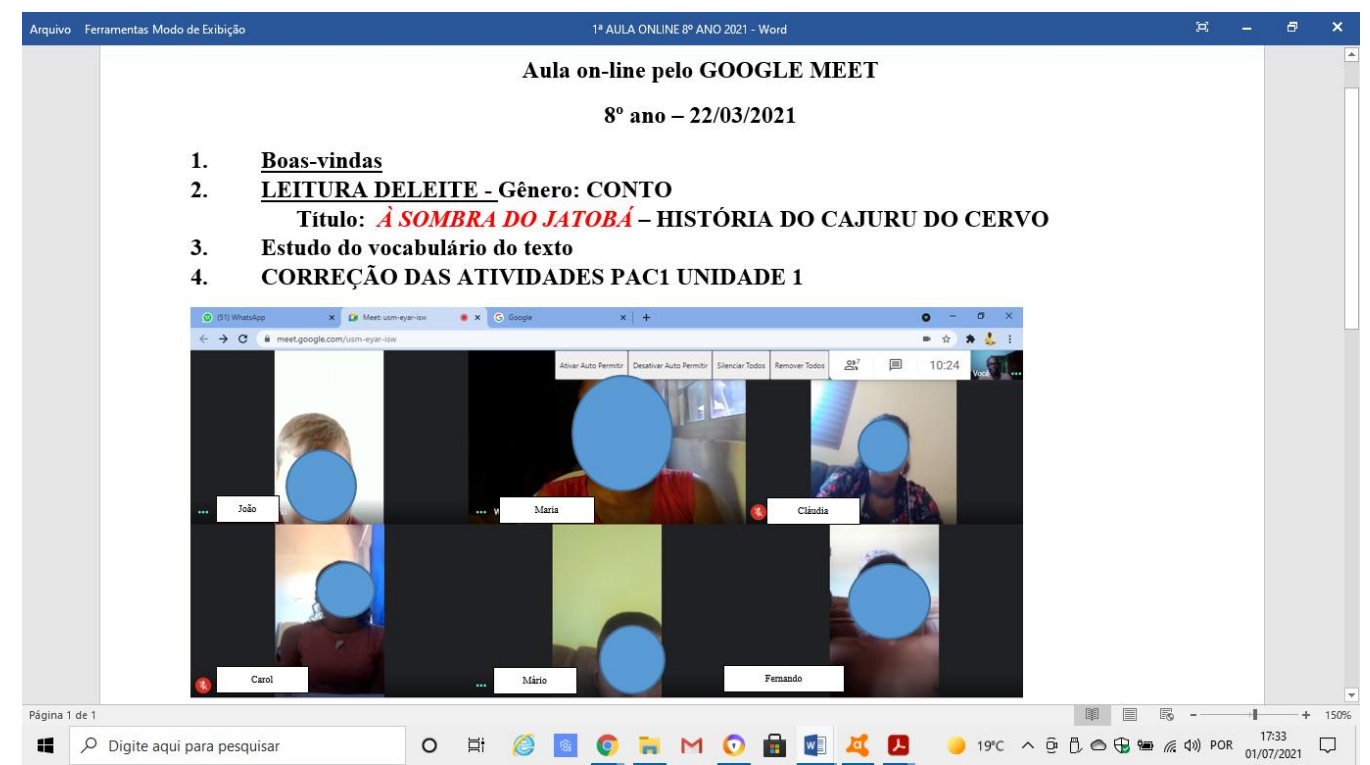

Figura 6: Estrutura da aula on-line de língua portuguesa

Fonte: Dos autores (2021)

Nas Boas-vindas, procuramos nos reaproximar dos alunos, criando um clima descontraído, para que os alunos se sintam à vontade para exporem suas preocupações, seus anseios, dúvidas e expectativas.

Na Leitura Deleite, traçamos como objetivo trabalhar a leitura na perspectiva de que os alunos precisam de bons modelos de leitores, ou seja, para que os alunos se interessem pela leitura e se tornem bons leitores, é necessário que eles tenham os professores como seus exemplos de leitores. Então, para esse momento da aula, trazemos para os alunos um gênero textual definido antecipadamente, escolhendo a modalidade de leitura de acordo com uma intencionalidade. O texto apresentado na aula do dia 22/03/2021 (Figura 6) é um conto, escrito pelo professor da disciplina de língua portuguesa, que fala do surgimento da 
comunidade rural onde os alunos moram. A intenção era levar os alunos a conhecerem a história do lugar onde moram, seus personagens, sua cultura e seus valores. Além disso, conscientizar os alunos sobre a importância da leitura ("Ler para quê?”): para se divertir, para localizar informações, para saber mais, para tirar dúvidas, para escrever, para aprender a montar alguma coisa, para identificar a intenção do escritor e construir e re(construir) significados, para descobrir o que deve ser feito ou para revisar, buscando erros e inadequações etc. (OLIVEIRA; ARAUJO, 2018, p. 15). Na dinâmica da leitura, seguimos alguns procedimentos preparando os alunos para leitura, tais como: começar pelo título, verificando que pistas estão presentes nele; discutir sobre as expectativas dos alunos com relação ao texto a ser lido; levantamento de hipóteses, etc. Durante a leitura, optamos por realizá-la na forma oral compartilhada (como estratégia para o desenvolvimento, por exemplo, das propostas de atividades que ocorrem durante a leitura), leitura dirigida (solicitando que o aluno leia o trecho de que mais gostou, que mais o emocionou, que lhe transmitiu determinada ideia) e, posteriormente, fazermos interpretação oral. $\mathrm{Na}$ interpretação oral, focamos, principalmente, em perguntas que fazem com que os alunos identifiquem o tema do texto, tais como "De que trata o texto?" e "O que o texto nos diz de mais importante?". E, para finalizarmos o momento de leitura, incentivamos os alunos a fazerem comentários sobre algum aspecto do texto (se gostaram, se não gostaram ou se dariam um outro fim para a história).

No Estudo do vocabulário do texto, ensinamos aos alunos sobre a importância de se pesquisar os significados das palavras: que ao se trabalhar com a pesquisa/procura de palavras, desenvolvemos competências e habilidades como seleção de informações, aprendemos a lidar com o dicionário ou com um tipo de pesquisa pela internet que exige de nós atenção para selecionar, entre tantos sites, aquele(s) que terão o que realmente procuramos e aprendemos e, também, a selecionar a expressão/vocábulo que defina corretamente a palavra procurada. Ainda explicamos que a pesquisa do significado das palavras enriquece o vocabulário e que todas as palavras possuem sinônimos, e que eles nos ajudam no momento da escrita. Na Correção das atividades dos PACs, tomamos as atividades postadas no grupo de Whatsapp de cada turma e realizadas pelos alunos, esclarecemos suas dúvidas e as corrigimos.

As aulas de língua portuguesa on-line são baseadas em um processo de comunicação interativa, na qual é o contexto social dos alunos que determina a maneira como a linguagem 
é utilizada. A nossa prática de ensino de língua portuguesa, principalmente durante o contexto de pandemia, em que estivemos distantes de nossos alunos, necessitou contemplar um ensino em que procuramos ensinar não apenas a escrever, mas principalmente a pensar; a pensar com eficácia e objetividade, e a escrever sem a obsessão do purismo gramatical, mas com a clareza, a objetividade e a coerência indispensáveis para fazer da linguagem, oral ou escrita, um veículo de comunicação. Aproveitamos o contexto em que vivemos para ensinar nossos alunos a pensar, a encontrar ideias, a organizá-las, a coordená-las, a concatená-las e a expressá-las por meio da linguagem de maneira eficaz, isto é, de maneira clara, coerente e enfática, isto é, a fazer uso da linguagem para estabelecer comunicação.

Assim, em meio ao contexto pandêmico, o conhecimento básico dos recursos tecnológicos, das tecnologias e os seus usos demonstraram que o trabalho pedagógico com linguagem pode acontecer em suas instâncias vivas, ou seja, por ser "social por excelência e qualquer processo que a envolva também o é.” (SANTOS, 2015, p. 20), é na interação verbal - produto da relação de dois sujeitos - que a linguagem se materializa em enunciados. Em vista disso, os professores, mesmo que minimamente letrados digitalmente, puderam utilizar dos recursos tecnológicos digitais para interagirem com seus alunos, utilizando-se da língua(agem) em sua inventividade, em que os enunciados criados por um e por outro geraram respostas, possibilitadas pelo uso de tais recursos.

\section{Considerações finais}

O professor de língua portuguesa que se proponha a ensinar conteúdos por meio de um ambiente virtual, necessitará pensar cuidadosamente em como estes serão e estarão dispostos no ambiente virtual. Além disso, pensar também em como os enunciados serão construídos, dado que precisarão ser adaptados ao contexto imediato (ambiente virtual e contexto social/real dos alunos), utilizando-se das linguagens próprias do recurso tecnológico escolhido, assim como ter clareza de quem são os interlocutores, sujeitos concretos participantes daquele contexto de ensino e aprendizagem. A não observância desses fatores poderá incorrer em uma "construção ideológica incorreta, criada sem considerar os dados concretos da expressão social" (BAKHTIN, 2003, p. 120).

Em outras palavras, ao pensarmos em ensinar por meio de um ambiente digital, alguns aspectos se mostram relevantes para melhor compor a linguagem, tais como conhecermos e sabermos como o recurso funciona, de modo a adaptarmos os conteúdos ao tipo de recurso 
tecnológico que pretendemos utilizar, para que tal recurso não seja utilizada para mera transposição do conteúdo presente nos livros didáticos, apostilas ou outros suportes, para o ambiente virtual. Compreendemos que, caso isso aconteça, estaremos cometendo uma "construção ideológica incorreta", conforme diz Bakhtin (2003, p. 120), gerando "interferências e distorções" no processo de ensino e aprendizagem, uma vez que a maneira como os aprendizes/leitores fazem leitura, aprendem por meio de suportes impressos, lidam com esses suportes e processam as informações presentes neles, difere da forma como leem, aprendem, se comunicam e lidam com informações obtidas por meio de textos digitais e da tela do computador.

Os conceitos teóricos de Bakhtin (2003), no que concerne ao jogo da comunicação linguística, nos faz compreender que o contexto social e as trocas estabelecidas entre os participantes do grupo social determinarão as condições em que o diálogo se situará e se a comunicação se efetivará. Tais conceitos nos fazem refletir sobre como os ambientes virtuais de aprendizagem devem ser e estar estruturados, no que diz respeito ao potencial interativo e comunicacional, dado que todos os conteúdos, os enunciados e as linguagens a serem utilizadas precisam favorecer o processo de ensino e aprendizagem, assim como também o processo comunicacional, uma vez que os participantes envolvidos na situação de ensino e aprendizagem fazem parte de um contexto e grupo social real. Bakhtin (2003, p. 124) proclama que "o centro organizador de toda enunciação, de toda expressão, não é interior, mas exterior: está situado no meio social que envolve o indivíduo”.

Vale ressaltar que, neste contexto, não deve prevalecer apenas o desejo do professor ou aquilo que está direcionado no livro didático que utiliza. Pois, tudo o que for planejado e organizado necessita ter como princípio motivador o contexto social em que vivem os alunos, para que as distâncias física, social, psicológica, emocional e cultural não sejam acentuadas, mas antes minimizadas.

O período em que estamos vivendo se constitui em uma oportunidade para trabalharmos, mais assiduamente, o aprimoramento da escrita dos alunos ou da aprendizagem de gramática, como também com a linguagem verbal e multimodal, orientando os alunos a pensar, a se expressar com clareza e objetividade, de modo a saberem o que, como e para quem dizer, escrever ou postar.

Advogamos que seja essencial que os professores de português tenham o propósito de ensinar o estudante a desenvolver a sua capacidade de raciocínio, a servir-se do seu espírito de 
observação para colher impressões a respeito do contexto que os cerca, a formar juízos, a descobrir ideias para ser tanto quanto possível exato, claro, objetivo e fiel na expressão de seu pensamento. Considerando que o ensino da língua se refere ao ensino da linguagem como forma de interação e intervenção social, de expressividade e comunicabilidade, advogamos que as situações de ensino remoto vivenciadas estimularam a compreensão do contexto da linguagem, do porquê, do para quê e para quem se escreve, em que a compreensão responsiva complementa o texto emitido pelo outro, pelo fato de ser "[...] ativa e criadora. O sujeito da compreensão não pode excluir a possibilidade de mudanças e até de renúncia aos seus pontos de vista e posições já prontos. No ato da compreensão desenvolve-se uma luta cujo resultado é a mudança mútua e o enriquecimento" (BAKHTIN/VOLOCHINOV, 2009, p. 378).

\section{Referências bibliográficas}

BAKHTIN, Mikhail. Os gêneros do discurso. In: BAKHTIN, M. Estética da Criação Verbal. São Paulo: Martins fontes, 2003.

BAKHTIN, Mikhail. (VOLOCHÍNOV). Marxismo e filosofia da linguagem. Problemas fundamentais do método sociológico na ciência da linguagem. Trad. Michel Lahud e Yara Frateschi Vieira. 13 ed. São Paulo: Hucitec, 2009 [1929].

BRASIL. Ministério da Educação. Conselho Nacional de Educação. Conselho Pleno. Parecer CNE/CP $\mathbf{n}^{\circ}$ 5, de 28 de abril de 2020. Disponível em: http://portal.mec.gov.br/index.php?option=com_docman\&view=download\&alias=145011 pcp005-20\&category_slug=marco-2020-pdf\&Itemid=30192. Acesso em: 7 jul. 2020.

FAIRCLOUGH, Norman. Language and globalization. London; New York, Routhedge: 2006.

FARDO, Marcelo Luís. A gamificação como estratégia pedagógica: estudo de elementos dos games aplicados em processos de ensino e aprendizagem. 2013. 106f. Dissertação (Mestrado em Educação) - Programa de Pós-Graduação em Educação, Universidade de Caxias do Sul, Caxias do Sul, 2013. Disponível em: https://www.semanticscholar.org/paper/A-gamifica\%C3\%A7\%C3\%A3o-comoestrat\%C3\%A9gia-pedag\%C3\%B3gica-\%3A-estudo-eFardo/bb9cb922420e3a20bfff8b78d160c63cb21b72e9\#citing-papers. Acesso em: 27 jun. 2021.

FRANCISCO, Edmilson. Blogs educacionais não instituições para ensino de língua portuguesa. 2019. 127f. Dissertação (Mestrado em Educação) - Programa de Pós-Graduação em Educação, Universidade Federal de Lavras, Lavras/MG, 2019. Disponível em: http://repositorio.ufla.br/jspui/bitstream/1/33253/2/DISSERTA\%C3\%87\%C3\%83O_Blogs\%2 
0educacionais $\% 20$ n\%C3\%A3o\%20institucionais\%20para\%20ensino\%20de\%201\%C3\%ADn gua\%20portuguesa.pdf Acesso em: 27 jun. 2021.

FREITAS, Maria Tereza de Assunção. Vigotski e Bakhtin - Psicologia e educação: um intertexto. São Paulo, Ática, 1994. Disponível em: https://www.scielo.br/j/es/a/HcwWWcdfJXY4PPShWZBBqkw/?lang=pt. Acesso em: 30 jun. 2021.

FREITAS, Maria Tereza de Assunção. Linguagem e transformação no diálogo com Bakhtin, volochinov e Vygotsky. In: PAULA, Luciane de. (Org.). Vozes discursivas. 1 ed. São Carlos: Pedro \& João Editores, 2020, 330 p.

FREITAS, Maria Tereza de Assunção. Letramento digital e formação de professores. Educação em Revista. Belo horizonte, v. 6, n. 03, p. 335-352, dez. 2010. Disponível em: http://www.scielo.br/pdf/edur/v26n3/v26n3a17/. Acesso em: 13 maio 2021.

ILARI, Rodolfo. A linguística e o ensino da língua portuguesa. São Paulo: Martins Fontes, 2001.

ISAIA, Sílvia Maria de Aguiar. Contribuições da Teoria Vygotskiana para uma fundamentação psico-epistemológica da educação. In: Freitas, M.T.A, (org.). Vygotsky um século depois. Juiz de Fora: EDUFJF, 1988. p. 21-34.

LOPES, Valdineia Prates Ribeiro; VIEIRA, Raphael Melzer; GABRIEL, Juliana Aparecida. A linguagem nos ambientes virtuais de aprendizagem e o perfil atual do aluno de língua estrangeira. Anais... ABEB (Associação Brasileira de Educação a Distância). São Paulo. 2020. Disponível em: http://www.abed.org.br/congresso2020/anais/trabalhos/56671.pdf. Acesso em: 30 jun. 2021.

MARX, Karl.; ENGELS, Friedrich. A ideologia alemã. Tradução: Rubens Enderle, Nélio Chneider e Luciano Cavino Martorano, $1^{a}$ ed. São Paulo: Editora Boitempo, 2006.

OLIVEIRA, Tania Amaral; ARAUJO, Lucy Aparecida Melo. Tecendo linguagens: língua portuguesa: $9^{\circ}$ ano. 5. ed. Barueri [SP]: IBEP, 2018.

PRENSKY, M. Digital natives, digital immigrants part 1. On the horizon, v. 9, n. 5, p. 1-6, 2001. Disponível em: http://doi.org/10.1108/10748120110424816 Acesso em 27 jun. 2021.

RIBEIRO, Ana Elisa; COSCARELLI, Carla Viana. (Orgs.). Letramento digital: aspectos sociais e possibilidades pedagógicas. Belo horizonte: autêntica, 2014.

RIBEIRO, Valéria Castro Zacharias. Letramento digital: desafios e possibilidades para o ensino. In: COSCARELLI, Carla Viana (Org.). Tecnologias para aprender. 1. ed. São Paulo: Parábola Editorial, 2016.

ROJO, Roxane; BARBOSA, Jacqueline Peixoto. Hipermodernidade, multiletramentos e gêneros discursivos. São Paulo: Parábola Editorial, 2015. 
SANTOS, André Cordeiro dos. Linguagem e construção de sentido: o dialogismo como característica base da interação verbal. Odisseia, Natal, RN, n. 15, p. 18-30, jul./dez. 2015. Disponível em: https://periodicos.ufrn.br/odisseia/article/view/9585. Acesso em: 30 mar. 2021.

VIEIRA, Josenia; SILVESTRE, Carminda. Introdução à Multimodalidade: Contribuições da Gramática Sistêmico-Funcional, Análise de Discurso Crítica, Semiótica Social. Brasília, DF: J. Antunes Vieira, 2015. 170 p.

XAVIER, Antonio Carlos dos Santos. Letramento Digital e ensino. In: SANTOS, Carmi Ferraz \& MENDONÇA, Márcia. Alfabetização e Letramento: conceitos e relações. Belo Horizonte: Autêntica, 2005.

Recebido em: 28/08/21

Aprovado em: 10/09/21 